\title{
The relevance of bisphenol A adsorption during Fenton's oxidation
}

\author{
A. Žgajnar Gotvajn • M. Bistan · T. Tišler • \\ A. J. Englande $\cdot$ J. Zagorc-Končan
}

Received: 24 January 2012/Revised: 21 May 2012/Accepted: 22 December 2012/Published online: 13 February 2013

(C) Islamic Azad University (IAU) 2013

\begin{abstract}
The aim of this research was to assess the efficiency of Fenton's oxidation for degradation of endocrine disruptor bisphenol A (BPA) with emphasis on extent of accompanying adsorption. Adsorption on the waste sludge resulting from the Fenton's oxidation could represent a significant impact on the final removal efficiency of BPA. Fenton's oxidation was accomplished at two concentrations of BPA $\left(0.228\right.$ and $\left.22.8 \mathrm{mg} \mathrm{L}^{-1}\right)$; both at the selected molar ratio of reagents $\mathrm{Fe}^{2+}: \mathrm{H}_{2} \mathrm{O}_{2}(1: 10)$, as a function of reaction time. The kinetics of adsorption of BPA on waste sludge was determined for the same two concentrations of BPA at two concentrations of waste sludge $\left(0.1\right.$ and $\left.6.0 \mathrm{~g} \mathrm{~L}^{-1}\right)$. In addition to changing concentrations of BPA and sludge, the adsorption process was also influenced by parameters such as temperature, $\mathrm{pH}$ and contact time. Adsorption isotherms were determined. Oxidation and adsorption were monitored by gas chromatography combined with mass spectrum. It has been confirmed that BPA is not completely oxidized in Fenton's oxidation, because it is adsorbed to formed waste ferric sludge and thus necessary precautions for sludge deposition must be observed.
\end{abstract}

\footnotetext{
A. Žgajnar Gotvajn $(\bowtie) \cdot$ J. Zagorc-Končan Faculty of Chemistry and Chemical Technology, University of Ljubljana, Aškerčeva 5, 1000 Ljubljana, Slovenia e-mail: andreja.zgajnar@fkkt.uni-lj.si

M. Bistan · T. Tišler

National Institute of Chemistry, Hajdrihova 19,

1001 Ljubljana, Slovenia

\section{A. J. Englande}

Department of Environmental Health Sciences, School of Public Health and Tropical Medicine, Tulane University, 1440 Canal Street, New Orleans, LA 70112, USA
}

Keywords Adsorption - Bisphenol A - Endocrine disrupters $\cdot$ Fenton's oxidation $\cdot$ Kinetic model

\section{Introduction}

During the last few decades, thousands of tonnes of manmade chemicals have been produced and released into the environment. Many of these chemical substances disrupt the function of the endocrine system of different organisms and are thus called endocrine disrupting substances (EDCs). EDCs may cover a variety of chemical classes including hormones, plant constituents, pesticides, compounds used in the plastics industry and other industrial byproducts and pollutants (Ternes and Joss 2006; Farre et al. 2008). They are associated with a variety of adverse health effects to wildlife and humans. EDCs mimic or block endogenous hormones and may modify the synthesis, transport, metabolism, or elimination of natural hormones (Mlynarcikova et al. 2005). Although it is still discussed whether such chemicals present a health hazard upon human beings, it is necessary to develop technology for their elimination to safeguard against potential harm to the environment and human health (Katsumata et al. 2004; Kazner et al. 2008).

Bisphenol A (BPA, CAS \#80-05-7) is an industrial chemical that is currently receiving a great deal of attention as an environmental contaminant (Kang et al. 2006). BPA is the key chemical used in the manufacture of polycarbonates and epoxy resins, materials that are utilized in a number of applications such as optical recording media, sports and medical equipment, beverage containers, etc. BPA is a wellknown endocrine disruptor, and is recognized as having both estrogenic and anti-estrogenic effects (Zoeller et al. 2005; Fujimoto et al. 2007). It has been detected with a high 
frequency, over $17.2 \mu \mathrm{g} \mathrm{L}^{-1}$ in landfill leachates (Yamamoto et al. 2001), up to $12 \mu \mathrm{g} \mathrm{L}^{-1}$ in surface waters (Kolpin et al. 2002) and up to $0.1 \mu \mathrm{g} \mathrm{L}^{-1}$ in drinking waters. This compound has been found to be present in wastewater effluents at low but environmentally relevant levels. This indicates that traditional treatment technologies may not be sufficiently effective for its removal (Citulski and Farahbakhsh 2010; Khanal et al. 2006).

Advanced oxidation processes (AOPs) are the oxidative degradation processes for organic compounds dissolved or dispersed in aquatic media by catalytic, chemical and photo-chemical methods (Andreozzi et al. 1999; Prousek 1996). These processes rely on the generation of organic radicals produced either by photolysis of organic substrate or by reaction with hydroxyl radicals (Kavitha and Palanivelu 2004). In AOPs, the hydroxyl radicals (OH·) are generated in the solution and these are responsible for the oxidation and mineralization of the organic compounds to water and carbon dioxide (Movahedyan et al. 2009). Among AOPs, Fenton's reagent $\left(\mathrm{Fe}^{2+} / \mathrm{H}_{2} \mathrm{O}_{2}\right)$ is becoming more and more common for the treatment of contaminated water. Fenton's reagent, a mixture of ferrous iron (catalyst) and hydrogen peroxide (oxidizing agent), is known as a powerful oxidant for organic contaminants (Kang and Hwang 2000; Neyens and Baeyens 2003). Iron is a highly abundant and non-toxic element, and hydrogen peroxide is easy to handle environmentally. There are, however, several disadvantages to the method: the highly to moderately acidic environmental $(\mathrm{pH} 2-5)$ which is required; and, the need to recover the $\mathrm{Fe}^{2+}$ or $\mathrm{Fe}^{3+}$ ions following treatment (Abo-Farha 2010: Qiang et al. 2003). The main weakness of the Fenton's process is formation of waste sludge, containing various iron salts and hydroxyls (Simon 2004); Ma and Xia 2009). Mass of the sludge is dependent upon the ratio and the volume of added reagents. As a consequence, the problem of adsorption of pollutants could potentially occur in the case of larger amounts of waste sludge present (Dong et al. 2010; Prousek 1996). This may result in significant contribution of adsorption which may reduce efficiency of oxidation processes leading to less effective destruction of pollutants (Fei et al. 2011).

The objectives of this research are: (1) to determine the contribution of adsorption of BPA to waste ferric sludge in the Fenton's process; (2) to evaluate the usefulness of a pseudosecond-order model for describing the adsorption mechanism; and, (3) to investigate the applicability of the Freundlich isotherm model to describe the BPA adsorption process.

\section{Materials and methods}

First, Fenton's oxidation experiments were conducted, the concentration of waste ferric sludge was determined at different operational conditions, followed by adsorption experiments to determine an appropriate kinetic model to describe the adsorption process. The impact of $\mathrm{pH}$ and temperature to adsorption was also studied.

Bisphenol A (2,2-bis-(hydroxyphenyl)propane, BPA p.a.) was obtained from Sigma, Germany. Stock solutions of BPA $\left(0.228\right.$ and $\left.22.8 \mathrm{mg} \mathrm{L}^{-1}\right)$ were prepared by dissolving appropriate amounts of test substance in ethanol (96 \%, $1 \mathrm{~mL}$ ). For Fenton's oxidation ferrous sulfate heptahydrate $\left(\mathrm{FeSO}_{4} \cdot 7 \mathrm{H}_{2} \mathrm{O}\right.$; Fluka Analytical, Germany) and hydrogen peroxide $\left(\mathrm{H}_{2} \mathrm{O}_{2}, 30 \%\right.$; Merck, Germany) were used. The $\mathrm{pH}$ was adjusted by addition of concentrated $\mathrm{HCl}$ (Merck, Germany) and $\mathrm{NaOH}$ (Merck, Germany) for all experiments. Experiments were run in duplicates.

\section{Fenton's oxidation}

Fenton's processes were carried out in 2,000 mL beakers with a solution volume of $800 \mathrm{~mL}$. Solution of the test substance BPA $\left(0.228\right.$ or $\left.22.8 \mathrm{mg} \mathrm{L}^{-1}\right)$ was placed in a beaker and mixed at $200 \mathrm{rpm}$. Optimum pH was adjusted to 2.5-3.0. The Fenton's process was carried out by adding $\mathrm{FeSO}_{4} \cdot 7 \mathrm{H}_{2} \mathrm{O}$ and $\mathrm{H}_{2} \mathrm{O}_{2}$ at 1:10 molar ratio with no temperature adjustment. Because of the low concentrations of reagent (at $0.228 \mathrm{mg} \mathrm{L}^{-1}$ of $\mathrm{BPA}$ molar ratio of $\mathrm{Fe}^{2+}: \mathrm{H}_{2} \mathrm{O}_{2}$ was 0.001:0.01 $\mathrm{M}$ and at $22.8 \mathrm{mg} \mathrm{L}^{-1}$ of BPA it was $0.1: 1 \mathrm{M})$, the temperature remained in the $22 \pm 1{ }^{\circ} \mathrm{C}$ range in spite of the exothermic nature of the process. At different time periods $(0,5,10,30,50$ and 70 min) samples were withdrawn and the $\mathrm{pH}$ value was increased with $\mathrm{NaOH}$ to 12.0 to stop the reaction. Samples were boiled afterward for about $10 \mathrm{~min}$ to remove the remaining $\mathrm{H}_{2} \mathrm{O}_{2}$. Samples were cooled and filtered through a black ribbon. To determine the concentration of BPA after Fenton's oxidation GC-MS analyses were performed on filtered samples. The impact of the procedure itself on BPA concentration was assessed separately. $800 \mathrm{~mL}$ of BPA $\left(0.228 \mathrm{mg} \mathrm{L}^{-1}\right)$ was prepared and the $\mathrm{pH}$ was adjusted to 2.5 and mixed for $70 \mathrm{~min}$. Then the $\mathrm{pH}$ was increased to 12.0 and boiled for $10 \mathrm{~min}$. After filtration, the concentration of BPA was determined and was found to be reduced for $3.2 \pm 1.2 \%(n=2)$.

\section{Adsorption experiments}

For adsorption experiments waste sludge was prepared separately under uniform conditions. $55.6 \mathrm{~g}$ of $\mathrm{FeS}$ $\mathrm{O}_{4} \cdot 7 \mathrm{H}_{2} \mathrm{O}$ and $204 \mathrm{~mL}$ of $30 \% \mathrm{w} / \mathrm{v} \mathrm{H}_{2} \mathrm{O}_{2}$ were added in $0.5 \mathrm{~L}$ of distilled water. The ferrous sludge formed was neutralized with $5 \mathrm{M} \mathrm{NaOH}$, boiled and allowed to settle. After $30 \mathrm{~min}$, the liquid was decanted while the remaining sludge was dried in a dryer at $105 \pm 1{ }^{\circ} \mathrm{C}$ for 2 days until a constant mass was obtained. Dry sludge was homogenized 
and sieved $(0.2 \mathrm{~mm})$ to ensure comparable size of sludge particles.

The effect of contact time on the adsorption process was studied in $2,000 \mathrm{~mL}$ beakers at ambient temperature $\left(22 \pm 2{ }^{\circ} \mathrm{C}\right)$ with BPA concentrations of 0.228 and $22.8 \mathrm{mg} \mathrm{L}^{-1}$. Waste sludge (adsorbent) was added at a concentration of $0.1 \mathrm{~g} \mathrm{~L}^{-1}$. The selection of concentrations of waste sludge was based on average concentration of sludge formed during Fenton's oxidation at the low concentration of BPA $\left(0.228 \mathrm{mg} \mathrm{L}^{-1}\right)$. The reaction was conducted without $\mathrm{pH}$ adjustment. During $2 \mathrm{~h}$ of mixing, samples were withdrawn every few minutes and BPA concentrations were measured. To determine the activation energy of the adsorption process, $0.228 \mathrm{mg} \mathrm{L}^{-1}$ of BPA was used with $0.1 \mathrm{~g} \mathrm{~L}^{-1}$ of waste sludge. The reaction was carried out without $\mathrm{pH}$ adjustment at three different temperatures: 10, 20 and $30 \pm 2{ }^{\circ} \mathrm{C}$. During $2 \mathrm{~h}$ of mixing, samples were withdrawn every few minutes and BPA concentrations were determined.

The study on the effect of adsorbent dose (waste sludge) on adsorption efficiency was performed at ambient temperature $\left(22 \pm 2{ }^{\circ} \mathrm{C}\right)$ without $\mathrm{pH}$ adjustment. Experiments were done using two concentrations of BPA $\left(0.228\right.$ and $\left.22.8 \mathrm{mg} \mathrm{L}^{-1}\right)$. The sample volume was $50 \mathrm{~mL}$. Adsorbent doses were varied from 0.0 to $0.5 \mathrm{~g} \mathrm{~L}^{-1}$ for the lower concentration of BPA, and from 0.0 to $10.0 \mathrm{~g} \mathrm{~L}^{-1}$ for the higher concentrations of BPA. The systems were mixed for $45 \mathrm{~min}$ prior to analytical determination. The effect of BPA dose (0.228 vs. $22.8 \mathrm{mg} \mathrm{L}^{-1}$ ) was investigated at a low concentration of waste sludge $\left(0.1 \mathrm{~g} \mathrm{~L}^{-1}\right)$ and also at a higher concentration (6.0 $\left.\mathrm{g} \mathrm{L}^{-1}\right)$ under the same conditions $(60 \mathrm{~min})$.

To study the effect of initial $\mathrm{pH}$ on the process of adsorption, several experiments $(50 \mathrm{~mL}$ of the sample) at different initial pHs, ranging from 2.0 to 12.0 with an adsorbent dose of $0.1 \mathrm{~g} \mathrm{~L}^{-1}$ at the lower concentration of BPA $\left(0.228 \mathrm{mg} \mathrm{L}^{-1}\right)$, were carried out. Experiments were accomplished at ambient temperature $\left(22 \pm 2{ }^{\circ} \mathrm{C}\right)$ for about $45 \mathrm{~min}$. The appropriate initial $\mathrm{pH}$ was attained with $\mathrm{HCl}$ and $\mathrm{NaOH}$.

Freundlich adsorption isotherm model

The Freundlich isotherm is an empirical equation for the description of heterogeneous systems. Its application typically gives an accurate picture of adsorption of many organics from aquatic medium. The linear form of Freundlich equation is expressed:

$\log \left(q_{e}\right)=\log K_{F}+\frac{1}{n} \log C_{e}$

where $K_{\mathrm{F}}$ is the Freundlich adsorption constant $\left[\left(\mathrm{mg} \mathrm{g}^{-1}\right)\left(\mathrm{mg} \mathrm{L}^{-1}\right)^{1 / n}\right], n$ the empirical constant, $q_{\mathrm{e}}$ represents quantity of adsorbate per unit of adsorbent $\left(\mathrm{mg} \mathrm{g}^{-1}\right), C_{\mathrm{e}}$ is the equilibrium concentration of adsorbate in solution $\left(\mathrm{mg} \mathrm{L}^{-1}\right)$.

The constants $\left(K_{\mathrm{F}}\right.$ and $\left.n\right)$ in the Freundlich isotherm can be determined by plotting $\log \left(q_{\mathrm{e}}\right)$ versus $\log C_{\mathrm{e}}$ (Bansal and Goyal 2005).

\section{Kinetic model of adsorption}

Several mathematical models have been proposed to describe adsorption data. They can be generally classified as adsorption reaction models and adsorption diffusion models. At present, adsorption reaction models have widely been accepted for description of kinetic processes of adsorption (Qiu et al. 2009). The modeling of kinetics of adsorption of BPA on waste sludge was investigated by two commonly used models, the Lagergren pseudo-firstorder model (Lagergren 1898) and pseudo-second-order model presented by Ho and McKay (1999).

Lagergren (1898) proposed a method for adsorption analysis which is the pseudo-first-order kinetic equation in the linear form:

$\log \left(q_{\mathrm{e}}-q_{t}\right)=\log \left(q_{\mathrm{e}}\right)-\left(\frac{k_{1}}{2.303}\right) t$

where $q_{\mathrm{e}}$ and $q_{t}$ are the amounts of BPA adsorbed at equilibrium in $\mathrm{mg} \mathrm{g}^{-1}$ and at time $t(\mathrm{~h})$, respectively, and $k_{1}$ is pseudo-first-order rate constant $\left(\mathrm{h}^{-1}\right)$. To distinguish kinetic equations based on adsorption capacity from solution concentration, this first-order reaction was called pseudo-first-order reaction (Ho and Mckay 1998). A linear plot of $\log \left(q_{\mathrm{e}}-q_{t}\right)$ against time allows one to obtain the kinetic rate constant. This model has been widely used in recent years to describe the adsorption of pollutants from wastewaters (Tan et al. 2008).

In some cases, a pseudo-second-order kinetics may apply as expressed by Ho and McKay (1999):

$\frac{t}{q_{t}}=\frac{1}{k_{2} q_{\mathrm{e}}^{2}}+\left(\frac{1}{q_{\mathrm{e}}}\right) t$

where $k_{2}\left(\mathrm{~g} \mathrm{mg}^{-1} \mathrm{~h}^{-1}\right)$ is rate constant of adsorption, $q_{\mathrm{e}}$ $\left(\mathrm{mg} \mathrm{g}^{-1}\right)$ is the amount of BPA adsorbed at equilibrium and $q_{t}\left(\mathrm{mg} \mathrm{g}^{-1}\right)$ is the amount of BPA adsorbed at time $t$ (h). $\ln k_{2}=\ln A-\frac{E_{A}}{R} \cdot \frac{1}{T}$ represents the initial adsorption rate. This model has been successfully applied for studying adsorption of metal ions, dyes, herbicides and various organics from aqueous solutions (Qiu et al. 2009). The terms $q_{\mathrm{e}}$ and $k_{2}$ can be determined experimentally from the slope and intercept from a plot $t / q_{t}$ versus time. $k_{2}$ may also be used for determination of activation energy $\left(E_{\mathrm{a}}\right.$, $\mathrm{kJ} \mathrm{mol}^{-1}$ ):

$\ln k_{2}=\ln A-\frac{E_{\mathrm{a}}}{R} \cdot \frac{1}{T}$ 
where $k_{2}\left(\mathrm{~g} \mathrm{mg}^{-1} \mathrm{~h}^{-1}\right)$ is the rate constant of adsorption, $A$ the frequency factor $\left(\mathrm{g} \mathrm{mg}^{-1} \mathrm{~min}^{-1}\right), E_{\mathrm{a}}$ the activation energy $\left(\mathrm{kJ} \mathrm{mol}^{-1}\right), R$ the gas constant $\left(8.314 \mathrm{~J} \mathrm{~mol}^{-1} \mathrm{~K}^{-1}\right)$ and $T$ is the temperature (K).

\section{Analytical method (SPME/GC-MS)}

Eighteen milliliters of each filtered sample was transferred directly to a $20 \mathrm{~mL}$ glass vial to perform SPME/GC-MS analysis. SPME/GC-MS analysis was performed on GC Agilent Technologies 6890 coupled with a MSD 5730 detector. The Gerstel MPS autosampler was used to allow automated SPME analysis. Samples were exposed to microextraction procedure (SPME) using SPME fiber (Supelco, Sigma-Aldrich) coated with polyacrylate (PA) $85 \mu \mathrm{m}$ (Brondi and Lancas 2005; Eisert and Levsen 1996). The PA fiber was conditioned in the hot injector of the gas chromatograph according to the instructions provided by the supplier. The samples were incubated at $55^{\circ} \mathrm{C}$ for $2 \mathrm{~min}$. Adsorption of compounds from water samples on the PA $85 \mu \mathrm{m}$ fiber was carried out by stirring the vial on the agitator for $30 \mathrm{~min}$ at $55^{\circ} \mathrm{C}$ and a stirring speed of $250 \mathrm{rpm}$ (Brondi and Lancas 2005). After adsorption, the PA $85 \mu \mathrm{m}$ fiber was transferred to the injector port where thermal desorption at $250{ }^{\circ} \mathrm{C}$ occurred. Compounds were separated on the gas chromatograph equipped with a splitsplitless injector, operating in the splitless mode and using a $30 \mathrm{~m}$ length, $0.25 \mathrm{~mm}$ I.D., $0.25 \mu \mathrm{m}$ film thickness HP5MS (5\% phenyl-methylpolysiloxane, Agilent) capillary column. Helium was used as carrier gas with a flow rate of $1.1 \mathrm{~mL} \min ^{-1}$. The initial oven temperature was set at $80{ }^{\circ} \mathrm{C}$ with an initial 4 min hold during the desorption step, followed by a programed temperature ramp $15{ }^{\circ} \mathrm{C} \mathrm{min}{ }^{-1}$ up to the final temperature of $300{ }^{\circ} \mathrm{C}$, where it was held for another $10 \mathrm{~min}$. MS monitoring conditions were set as follows: transfer line temperature was $280{ }^{\circ} \mathrm{C}$ and detector voltage was $350 \mathrm{~V}$. The MS signal was collected over 50-300 $\mathrm{mz}^{-1}$. Electron impact ionization in the positive mode and scan acquisition mode were used.

\section{Results and discussion}

Fenton's oxidation

The removal efficiency of BPA at two different concentrations $\left(0.228\right.$ and $\left.22.8 \mathrm{mg} \mathrm{L}^{-1}\right)$ by Fenton's oxidation at one molar ratio of Fenton's reagents $\mathrm{Fe}^{2+}$ and $\mathrm{H}_{2} \mathrm{O}_{2}$ (1:10) was studied (Figs. 1, 2). In both cases removal of BPA was rapid. At lower concentration of BPA, $92 \%$ of it was removed in $10 \mathrm{~min}$, the final removal level, attained in 90 min was $96 \pm 3 \%$ (Fig. 1). At the higher concentration of BPA (22.8 $\mathrm{mg} \mathrm{L}^{-1}$, Fig. 2), its concentration was reduced $93 \pm 4 \%$ in the first $5 \mathrm{~min}$.

The concentration of waste ferric sludge was also determined following both experiments. The average sludge production in two parallel experiments at $0.228 \mathrm{mg} \mathrm{L}^{-1}$ of BPA was $0.10 \pm 0.05 \mathrm{~g} \mathrm{~L}^{-1}$ and at $22.8 \mathrm{mg} \mathrm{L}^{-1}$ it was $6.0 \pm 0.5 \mathrm{~g} \mathrm{~L}^{-1}$. It was estimated that the amount of sludge in both cases is significant and it can vary under the same experimental conditions due to different side reactions depending upon the ratio of reagents, physico-chemical conditions and nature of organics present. Formed ferric hydroxo complexes are mainly responsible for the coagulation capacity of Fenton's reagents (Neyens and Baeyens 2003). Due to the fine dispersion and structure of formed flocs, it is assumed that they possess large accessible internal and/or external surface, known for different adsorbents. Due to the fact that the BPA is well known by its adsorption potential to soils and minerals (Tsai et al. 2006),
Fig. 1 Removal of BPA (initial $\left.[\mathrm{BPA}]=0.228 \mathrm{mg} \mathrm{L}^{-1}\right)$ and its concentration versus time in Fenton's oxidation

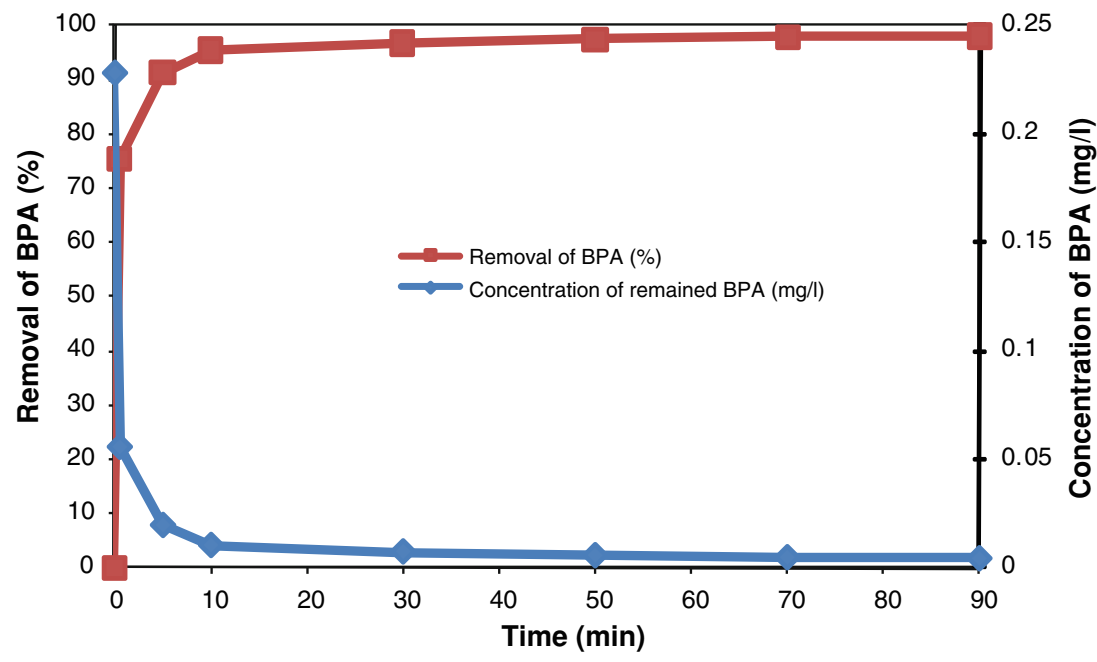


Fig. 2 Removal of BPA (initial [BPA] $=22.8 \mathrm{mg} \mathrm{L}^{-1}$ ) and its concentration versus time in Fenton's oxidation

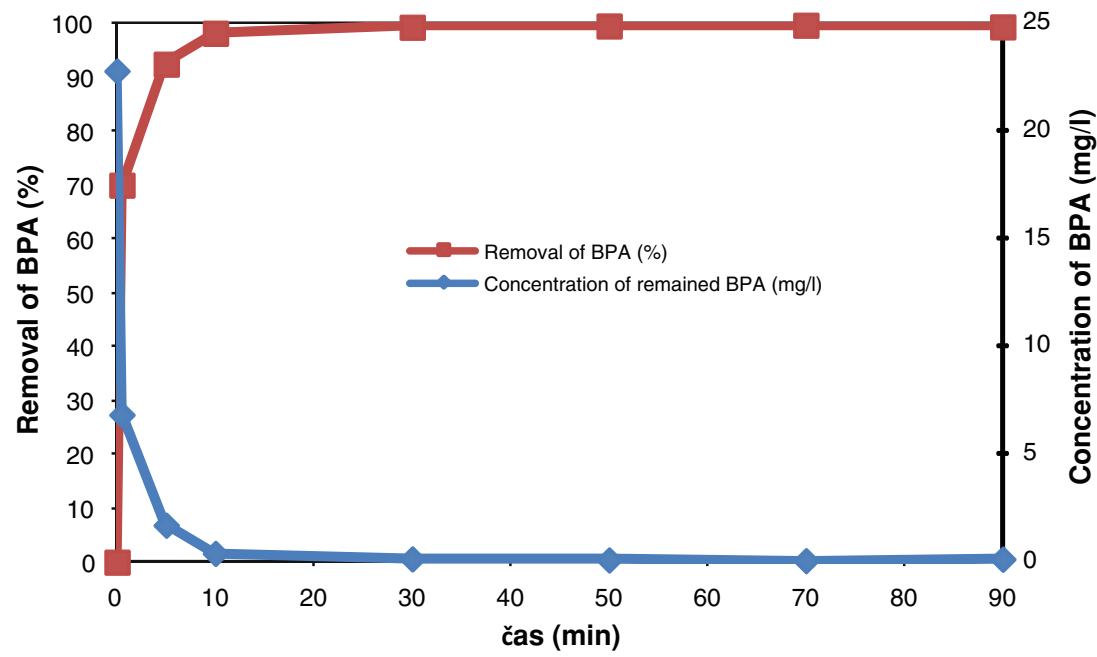

it was assumed that it can adsorb also waste Fenton's sludge. Therefore, high removal efficiencies (Figs. 1, 2) cannot be assigned to the oxidation process only.

\section{Adsorption experiments}

The effect of contact time to the adsorption process of BPA to Fenton sludge was studied at both concentrations of BPA $\left(0.228 / 22.8 \mathrm{mg} \mathrm{L}^{-1}\right)$. The equilibrium between liquid and solid phase was attained at the lower concentration after 40 min (90\% of BPA removal); while at the higher concentration $10 \mathrm{~min}$ was required to achieve a final $70 \%$ removal. Data from these two experiments were employed for adsorption analysis using the pseudo-second-order kinetics equation (Table 1) in the linear form (Eq. 3). The measured data did not fit well for the pseudo-first-order kinetics presented as Eq. $2\left(r^{2}=0.7900-0.8100\right)$. For both concentrations of the BPA, the experimental data fit the applied pseudo-second-order model very well. The same BPA behavior was also confirmed by other authors, dealing with mineral adsorbents (Tsai et al. 2006). Data obtained at the lower concentration of BPA were also used for determination of activation energy (Eq. 4). $E_{\mathrm{a}}$ was $6.64 \mathrm{~kJ} \mathrm{~mol}^{-1}$ and the frequency factor A was $29.86 \mathrm{~g} \mathrm{mg}^{-1} \mathrm{~min}^{-1}$. Both values are quite low, indicating a weak interaction between adsorbate (BPA) and waste Fenton's sludge (Tsai et al. 2006).

The study on the effect of adsorbent dose (waste sludge) to adsorption efficiency was performed with both concentrations of BPA $\left(0.228\right.$ and $\left.22.8 \mathrm{mg} \mathrm{L}^{-1}\right)$ and the results were correlated using Freundlich adsorption isotherm (Eq. 1, Table 2). Data did not fit this adsorption model $\left(r^{2}=0.3759-0.4721\right)$. The Freundlich parameter $\left(K_{\mathrm{f}}\right)$ can be used as a relative indicator of adsorption capacity. Zeng et al. (2006) confirmed that in the case of BPA, it increases
Table 1 Parameters of the pseudo-second-order model at both initial concentrations of BPA

\begin{tabular}{lll}
\hline & \multicolumn{2}{l}{ Initial concentration of BPA } \\
\cline { 2 - 3 } & $0.228 \mathrm{mg} \mathrm{L}^{-1}$ & $22.8 \mathrm{mg} \mathrm{L}^{-1}$ \\
\hline Model equation & $\frac{t}{q_{t}}=0.3947+0.4819 \times t$ & $\frac{t}{q_{t}}=0.0292+0.3646 \times t$ \\
& $\left(r^{2}=0.9995\right)$ & $\left(r^{2}=1.0000\right)$ \\
$q_{\mathrm{e}}\left(\mathrm{mg} \mathrm{g}^{-1}\right)$ & 2.08 & 2.70 \\
$k_{2}\left(\mathrm{~g} \mathrm{mg}^{-1} \mathrm{~h}^{-1}\right)$ & 1.70 & 4.60 \\
\hline
\end{tabular}

with the increasing organic carbon content in the sediment. $K_{\mathrm{f}}$ values are also very high in the case of BPA adsorption to activated carbon, e.g. from 206.1 to 253.8 $\left(\mathrm{mg} \mathrm{g}^{-1}\right)\left(\mathrm{mg} \mathrm{L}^{-1}\right)^{1 / n}$. In the case of natural river sediments, however, they are much lower, e.g. 0.0072-0.0178 $\left(\mathrm{mg} \mathrm{g}^{-1}\right)\left(\mathrm{mg} \mathrm{L}^{-1}\right)^{1 / n}$ (Tsai et al. 2006; Zeng et al. 2006). Parameter $n$ is used as indicator of whether adsorption remains constant $(n=1)$ or decreases with increasing solute concentration $(n<1)$. In our case, it was less than 1 suggesting a low adsorption capacity (Zeng et al. 2006). Langmuir model has been applied as well (Bansal and Goyal 2005), but correlation between $C_{\mathrm{e}} / q_{\mathrm{e}}$ and $q_{\mathrm{e}}$ was even lower $\left(r^{2}=0.0237-0.1291\right)$. This was in accordance with low $E_{\mathrm{a}}$ and $A$ values confirming week interactions between BPA and sludge. However, poor correlations in both cases could also be a result of sludge behavior, which after introducing in the test system started to act as a catalyst resulting in at least minimal oxidation of the BPA complicating adsorption data. At the same time, the initial $\mathrm{pH}$ in the system with $22.8 \mathrm{mg} \mathrm{L}^{-1}$ of BPA decreased from 11.5 to 9.2 in $45 \mathrm{~min}$ of experiments. Lower $\mathrm{pH}$ could activate waste ferric sludge in terms of oxidation capability and thus oxidation of BPA may interfere with the adsorption mechanism. As a result, adsorption isotherms could not be reliably evaluated. 
Table 2 Freundlich adsorption isotherm at both initial concentrations of BPA
Initial concentration of BPA

$0.228 \mathrm{mg} \mathrm{L}^{-1} \quad 22.8 \mathrm{mg} \mathrm{L}^{-1}$

\begin{tabular}{lll}
\hline Model equation & $\log \left(q_{\mathrm{e}}\right)=1.1461+1.344 \times \log \left(C_{\mathrm{e}}\right)$ & $\log \left(q_{\mathrm{e}}\right)=1,3238+4,1996 \times \log \left(C_{\mathrm{e}}\right)$ \\
& $\left(r^{2}=0.4721\right)$ & $\left(r^{2}=0.3759\right)$ \\
$n$ & 0.744 & 0.238 \\
$K_{\mathrm{F}}\left[\left(\mathrm{mg} \mathrm{g}^{-1}\right)\left(\mathrm{mg} \mathrm{L}^{-1}\right)^{1 / n}\right]$ & 13.99 & 21.08 \\
\hline
\end{tabular}

Fig. 3 Adsorption of BPA and its equilibrium concentration versus different initial BPA concentrations at $0.1 \mathrm{~g} \mathrm{~L}^{-1}$ of waste sludge
Fig. 4 Adsorption of BPA and its equilibrium concentration versus different initial BPA concentrations at $6.0 \mathrm{~g} \mathrm{~L}^{-1}$ of waste sludge
Fig. 5 Adsorption of BPA $\left(0.228 \mathrm{mg} \mathrm{L}^{-1}\right)$ and its concentration versus $\mathrm{pH}$ at $0.1 \mathrm{~g} \mathrm{~L}^{-1}$ of waste sludge
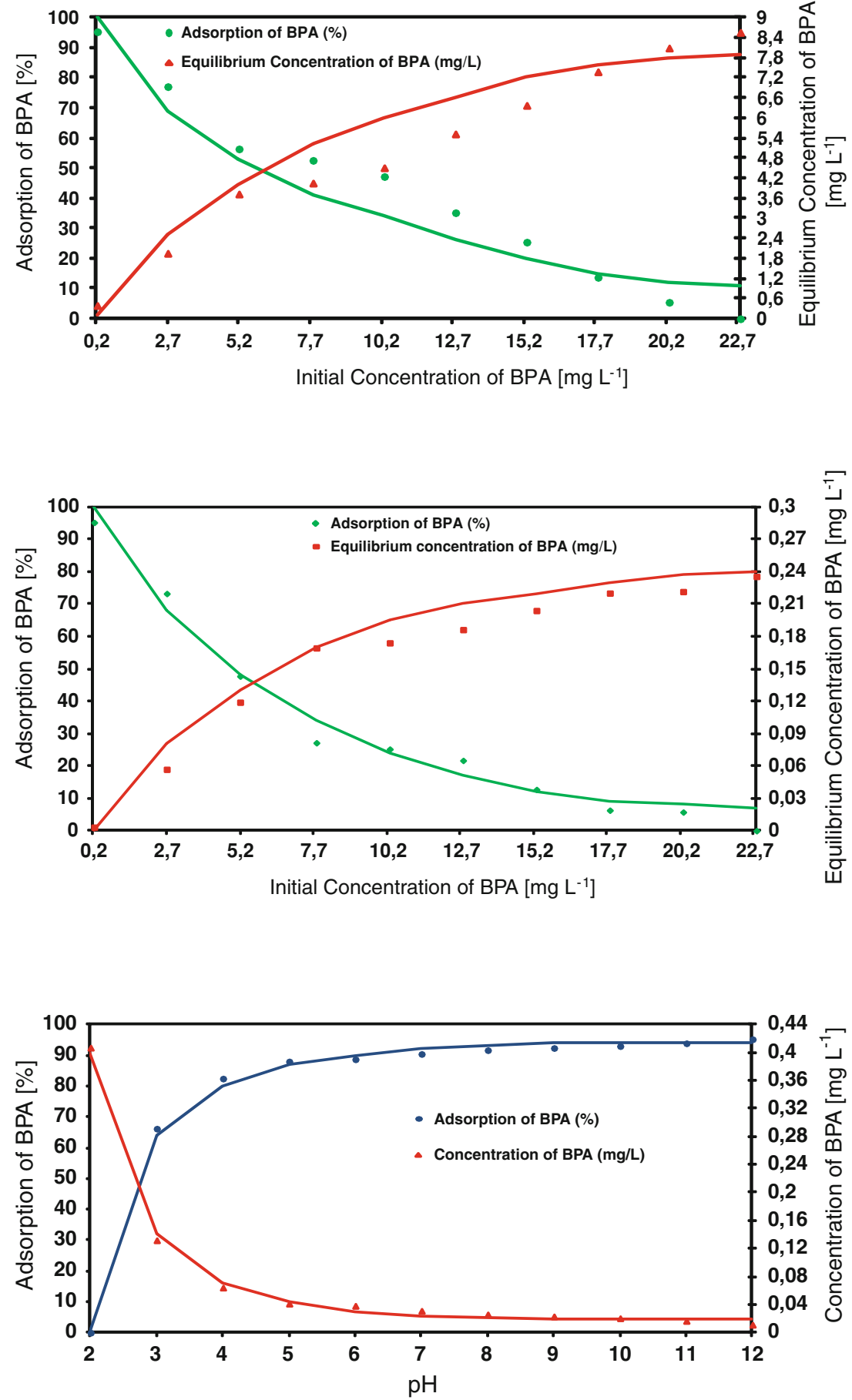
At $0.228 \mathrm{mg} \mathrm{L}^{-1}$ of BPA, adsorption in \% increased up to $0.01 \mathrm{~g} \mathrm{~L}^{-1}$ of sludge added; while at higher concentrations of ferric sludge, it remained more or less constant $(90 \pm 4 \%)$. The same was also true for the high concentration of BPA $\left(22.8 \mathrm{mg} \mathrm{L}^{-1}\right)$, where adsorption in $\%$ increased up to $2.0 \mathrm{~g} \mathrm{~L}^{-1}$ of the sludge added $(87 \pm 5 \%)$. Data from both experiments were comparable. At the lower concentration of BPA, $22.8 \mathrm{mg}$ of the substance was removed with $1 \mathrm{~g}$ of adsorbent; while at higher BPA concentration $11.4 \mathrm{mg}$ per $1 \mathrm{~g}$ of sludge was eliminated. It can be concluded that in both cases BPA was almost completely removed from the solution. Again, like in the Fenton's experiment, where we were unable to distinguish between oxidation and adsorption (Figs. 1, 2), we were unable to evaluate the ratio between adsorption and oxidation also in this set of experiments.

The impact of the amount of BPA on the adsorption process at lower and at higher concentrations of waste sludge is presented in Figs. 3 and 4, respectively. The $\%$ of adsorption is lower at the higher initial concentration of BPA. Initial concentration does not provide enough driving force to overcome the mass transfer resistance between the aqueous and solid phase. $\log K_{\text {ow }}$ of BPA is estimated to be in the range from 2.20 to 3.40 . Therefore, it is hydrophobic and binds more to organic adsorbents, e.g. activated carbon (Tsai et al. 2006). Also, its $\log K_{\text {oc }}$ is 2.49 , which indicates that it has a low-to-moderate potential to cling to the soils and sediments and that it can readily desorb because it is not tightly bound (Staples et al. 1998).

Obtained results (Figs. 3, 4) confirm previous experiments where BPA adsorption was studied at different amounts of adsorbent added. At $0.228 \mathrm{mg} \mathrm{L}^{-1}$ of BPA at $0.1 \mathrm{~g} \mathrm{~L}^{-1}$ of waste sludge obtained adsorption was $95 \pm 2 \%$; while in the case of $22.8 \mathrm{mg} \mathrm{L}^{-1}$ of BPA at $6.0 \mathrm{~g} \mathrm{~L}^{-1}$ of the sludge, it was $97 \pm 3 \%$.

Initial $\mathrm{pH}$ of the solution affects adsorption significantly (Fig. 5). The highest increase of adsorption was at $\mathrm{pH}$ 2.0-5.0, where it increased up to $90 \%$ and it continued to increase only slightly when the $\mathrm{pH}$ reached 9.0 . It remained constant at higher pHs. This can be correlated to the BPA $\mathrm{pKa}$ value, 9.6-10.2, indicating its ionization at high $\mathrm{pHs}$ and formation of bisphenolate anion ions; or, it is a consequence of possible negatively charged surface of the waste sludge (Tsai et al. 2006).

At pHs 2.5-3.0 which are used in Fenton's oxidation, $>30 \%$ adsorption was observed (Fig. 5). This leads to the conclusion that the contribution of adsorption in the Fenton's oxidation experiments (Figs. 1, 2) is significant (30-70\%), reducing the BPA oxidation efficiency to 30-70\%. Experiments indicated that lower $\mathrm{pH}$ favors oxidation. However, significant adsorption of BPA is expected during Fenton's oxidation leading to potential problems of waste ferric sludge disposal followed by possible leaching of entrapped BPA.

\section{Conclusion}

The efficiency of Fenton's oxidation for degradation of endocrine disruptor BPA has been studied. Due to the occurrence of waste ferric sludge during the oxidation process, up to several grams per liter, the relative importance of adsorption to sludge in comparison to oxidative removal was determined. The main conclusions are:

- Bisphenol A adsorbs on waste ferric sludge formed during Fenton's oxidation. In addition to the changing concentrations of BPA and sludge, the adsorption process is also influenced by parameters such as temperature, $\mathrm{pH}$ and contact time. The extent of adsorption increased with contact time (up to $40 \mathrm{~min}$ ), temperature and $\mathrm{pH}$. It is therefore very important to initiate the oxidation process at conditions which assure fast reaction (a few minutes) low pH (2.0) and ambient temperature.

- Experimental data fit an applied pseudo-second-order kinetic model. Low activation energy $\left(6.64 \mathrm{~kJ} \mathrm{~mol}^{-1}\right)$ and low frequency factor $\left(29.86 \mathrm{~g} \mathrm{mg}^{-1} \mathrm{~min}^{-1}\right)$ indicate weak interactions between adsorbate (BPA) and waste Fenton's sludge. This may lead to the desorption and leaching of BPA from the waste sludge after resuspension at the site of deposition.

- The study on the effect of adsorbent dose (waste sludge) to adsorption efficiency was performed used for calculation of the Freundlich and also Langmuir adsorption isotherm. Data did not fit adsorption models well ( $\left.r^{2}=0.237-0.4721\right)$ which may be a consequence of $\mathrm{pH}$ reduction during experiments and oxidative characteristics of the added sludge under more neutral conditions. Reliable determination of the adsorption isotherm was not possible.

It has been confirmed that BPA is not completely oxidized by Fenton's oxidation, since adsorption to the waste ferric sludge occurs and thus precautions must be taken for sludge deposition to avoid negative environmental and human health impacts.

Acknowledgments Authors are thankful to Mr. Matjaž Pevec and Mrs. Jana Nakrst for their excellent technical assistance. This work was supported by Slovenian Research Agency (ARRS) as a part of bilateral USA—Slovenia agreement BI/US/11-12-037 (2011-2012).

\section{References}

Abo-Farha A (2010) Comparative study of oxidation of some azo dyes by different advanced oxidation processes: Fenton, Fentonlike, photo-Fenton. J Am Sci 6:128-142

Andreozzi R, Caprio V, Insola A, Marotta R (1999) Advanced oxidation processes (AOP) for water purification and recovery. Catal Today 53:51-59 
Bansal RC, Goyal M (2005) Activated carbon adsorption. CRC Press/ Taylor \& Francis Group, Boca Raton, pp 145-159

Brondi SHG, Lancas FM (2005) Optimization of a methodology for the determination of organochlorine pesticides in surface water by SPME-GC/MS. J Environ Sci Health A 40:513-523

Citulski JA, Farahbakhsh K (2010) Fate of endocrine-active compounds during municipal biosolids treatment: a review. Environ Sci Technol 44:8367-8376

Dong Y, Wu D, Chen X, Lin Y (2010) Adsorption of bisphenol A from water by surfactant-modified zeolite. J Colloid Interface Sci 348:585-590

Eisert R, Levsen K (1996) Solid-phase microextraction coupled to gas chromatography: a new method for the analysis of organics in water. J Chromatogr 733:143-157

Farre M, Perez S, Katiani L, Barcelo D (2008) Fate and toxicity of emerging pollutants, their metabolites and transformation products in the aquatic environment. Trends Anal Chem 27: 991-1007

Fei Y, Li X-D, Li X-Y (2011) Organic diagenesis in sediment and its impact on the adsorption of bisphenol A and nonylphenol onto marine sediment. Mar Pollut Bull 63:578-582

Fujimoto T, Kubo K, Aou S (2007) Environmental impacts on brain functions: low dose effects of bisphenol A during perinatal critical period. Int Congr Ser 1301:226-229

Ho YS, McKay G (1998) A comparison of chemisorptions kinetic models applied to pollutant removal on various sorbents. Process Saf Environ 76(4):332-340

Ho YS, McKay G (1999) Pseudo-second order model for sorption processes. Process Biochem 34:451-465

Kang W, Hwang KY (2000) Effects of reaction conditions on the oxidation efficiency in the Fenton process. Water Res 34: 2786-2790

Kang JH, Kondo F, Katayama Y (2006) Human exposure to bisphenol A. Toxicology 226:79-89

Katsumata H, Kawebe S, Kaneco S, Suzuki T, Ohta K (2004) Degradation of bisphenol A in water by the photo-Fenton reaction. J Photochem Photobiol A Chem 162:297-305

Kavitha V, Palanivelu K (2004) The role of ferrous ion in Fenton and photo-Fenton for the degradation of phenol. Chemosphere 55: $1235-1243$

Kazner C, Lehnberg K, Kovalova L, Wintgens T, Melin T, Hollender J, Dott W (2008) Removal of endocrine and cytostatics from effluent by nanofiltration in combination with adsorption on powdered activated carbon. Water Sci Technol 8:1699-1706

Khanal SK, Xie B, Thompson ML, Sung S, Ong S-K, van Leeuvent J (2006) Fate, transport and biodegradation of natural estrogens in the environment and engineered systems. Environ Sci Technol 40(21):6537-6546

Kolpin DW, Furlong ET, Meyer MT, Thurman M, Zaugg SD, Barber LB, Buxton HT (2002) Pharmaceuticals, hormones, and other organic wastewater contaminants in U.S. streams, 1999-2000: a national reconnaissance. Environ Sci Technol 36:1202-1211

Lagergren S (1898) Zur theorie der sogenannten adsorption gelöster stoffe, Kungliga Svenska Vetenskapsakademiens. Handlingar 24:1-39 (in Swedish)

Ma X-J, Xia H-L (2009) Treatment of water-based printing ink wastewater by Fenton process combined with coagulation. J Hazard Mater 162:386-390

Mlynarcikova A, Kolena J, Fickova M, Scsukova S (2005) Alterations in steroid hormone production by porcine ovarian granulosa cells caused by bisphenol A and bisphenol A dimethacrylate. Mol Cell 244:57-62

Movahedyan H, Seid Mohammadi AM, Assadi A (2009) Comparison of different advanced oxidation processes degrading $p$-chlorophenol in aqueous solution. Iran $J$ Environ Health Sci Eng 6:153-160

Neyens E, Baeyens J (2003) A review of classic Fenton's peroxidation as an advanced oxidation technique. J Hazard Mater B98:33-50

Prousek J (1996) Advanced oxidation processes for water treatment. Chemical process. Chem Listy 90:229-237

Qiang Z, Chang J-H, Huang C-P (2003) Electrochemical regeneration of $\mathrm{Fe}^{2+}$ in Fenton oxidation processes. Water Res 37:1308-1319

Qiu H, Lv L, Pan B, Zhang Q, Zhang W, Zhang Q (2009) Critical review in adsorption kinetic models. J Zhejiang Univ Sci A 10(5):716-724

Simon P (2004) Advanced oxidation processes for water and wastewater treatment. IWA Publishing, London

Staples CA, Dorn PB, Klecka GM, O’Block ST, Harris LR (1998) A review of the environmental fate, effects and exposures of bisphenol A. Chemosphere 36(10):2149-2173

Tan IAW, Ahmad AL, Hameed BH (2008) Adsorption of basic dye on high-surface-area activated carbon prepared from coconut husk: equilibrium, kinetic and thermodynamic studies. J Hazard Mater 154(1-3):337-346

Ternes T, Joss A (2006) Human pharmaceuticals, hormones and flagrances: the challenge of micropollutants in urban water management. IWA Publishing, London, pp 45-52

Tsai W, Ali C, Su T (2006) Adsorption of bisphenol A from aqueous solution onto minerals and carbon adsorbents. J Hazard Mater B134:169-175

Yamamoto T, Yasuhara A, Shiraishi H, Nakasugi O (2001) Bisphenol A in hazardous waste landfill leachates. Chemosphere 42:415-418

Zeng G, Zhang C, Huang G, Yu J, Wang Q, Li J, Xi B, Liu H (2006) Adsorption behaviour of bisphenol A on sediments in Xiangjiang River, Central-south China. Chemosphere 65:1490-1499

Zoeller RT, Bansal R, Parris C (2005) Bisphenol-A an environmental contaminant that acts as a thyroid hormone receptor antagonist in vitro increases serum thyroxine and alters $\mathrm{RC} 3 /$ neurogranin expression in the developing rat brain. Endocrinology 146:607-612 